\title{
No strong association between alleles of tumour necrosis factor alpha and interleukin-1 receptor antagonist and corneal melting associated with systemic vasculitis
}

\author{
M McKibbin, B Clark, H Lee, J D Isaacs, H C Gooi, A J Morrell
}

\begin{abstract}
Aims-To investigate polymorphism within the tumour necrosis factor alpha (TNF- $\alpha$ ) promoter region and within the interleukin-1 receptor antagonist (IL$1 \mathrm{Ra})$ gene in a group of patients with vasculitis associated corneal melting.

Methods-The polymorphic regions at position -308 on the TNF-a promoter region and in intron 2 of the IL-1Ra gene were amplified by the polymerase chain reaction (PCR). The resultant products were separated by electrophoresis on agarose gels and visualised by ethidium bromide staining. Genotype and allele frequencies for the 20 patients were compared with healthy controls from the same geographical area.

Results-The allele frequencies in the patient and control groups respectively for the TNF- $\alpha$ and IL-1Ra sites studied were as follows: TNF1, 82.5\% and $80.2 \%$; TNF2, $17.5 \%$ and $19.8 \%$; IL-1Ra ${ }^{\star} 1,82.5 \%$ and $78.3 \%$; IL-1Ra ${ }^{\star} 2,15 \%$ and $20 \%$; IL-1Ra ${ }^{3}$ $2.5 \%$ and $1.5 \%$. Although there was a trend for the IL1Ra ${ }^{\star} 2$ allele to be more common in the control group, no allele was found to have a statistically significantly association with the patient group: TNF1 p = 0.89 ; TNF2 $p=0.89 ;$ IL-1Ra ${ }^{\star} 1 \mathrm{p}=0.65$; IL-1Ra ${ }^{\star} 2 p=0.68 ;$ IL-1Ra ${ }^{\star} 3 p=0.50$.

Conclusions-The results suggest that the polymorphic alleles of TNF- $\alpha$ and IL-1Ra studied play little or no part in the susceptibility to corneal melting among these patients with systemic vasculitis.

(Br f Ophthalmol 2000;84:395-398)
\end{abstract}

Ophthalmology, St

James's University

Hospital, Leeds

$M$ McKibbin

A J Morrell

Department of Immunology

B Clark

H Lee

H C Gooi

Department of Rheumatology

J D Isaacs

Correspondence to: Mr Martin McKibbin, Eye Clinic, Clarendon Wing, Leeds General Infirmary, Leeds LS2 9NS

Accepted for publication 8 December 1999 without inducing a biological effect. The IL-1 receptor antagonist (IL-1Ra) binds to the IL-1 receptor on the cell surface without inducing a biological effect and blocks the subsequent binding of IL-1. ${ }^{1}$ IL-1 Ra binds to both of the IL-1 receptors (IL-1RI and IL-1RII) but the binding to IL-1RI is responsible for most of the anti-inflammatory effect. ${ }^{1}$

TNF- $\alpha$, IL-1, and IL-1 Ra are secreted onto the healthy ocular surface by corneal and conjunctival epithelial cells. ${ }^{2}$ Production of the inflammatory cytokines increases after corneal injury but is regulated by local inhibitors. ${ }^{2-5}$ The effects of TNF- $\alpha$ and IL-1 include increased vascular permeability, induction of adhesion molecule expression, migration of inflammatory cells from the vascular compartment, release of inflammatory mediators causing tissue damage, such as metalloproteinases and nitric oxide, and the production of other cytokines. ${ }^{67}$ TNF- $\alpha$ and IL-1 have been implicated in anterior segment disease, including corneal melting. ${ }^{4}$ In contrast, IL-1 Ra may be involved in regulating corneal inflammation and repair. ${ }^{39}$

Polymorphism exists within the genome for both TNF- $\alpha$ and IL-1Ra. Although several of these polymorphisms are biologically silent, others have functional consequence and may be responsible for the high but stable interindividual variation in cytokine production. The gene encoding TNF- $\alpha$ lies on chromosome 6 between the MHC class 1 and class 2 regions. The TNF2 allele is characterised by an adenine to guanine substitution at position -308 relative to the transcription initiation site and is associated with increased TNF- $\alpha$ transcription. ${ }^{10}{ }^{11}$ The gene for IL-1Ra lies on chromosome 2 and contains an 86 base pair variable number tandem repeat (VNTR) within the second intron. ${ }^{12}$ Five alleles exist as variable numbers of the tandem repeat and allele 2, consisting of two repeats, is associated with increased transcription. ${ }^{13}$

Corneal melting or necrotising keratitis occurs most commonly in association with autoimmune vasculitis, particularly rheumatoid arthritis and Wegener's granulomatosis. ${ }^{14}$ The aetiology of these autoimmune disorders is multifactorial and both TNF- $\alpha$ and IL-1 have been implicated in the pathogenesis and targeted in treatment. ${ }^{715}$ Polymorphisms of TNF- $\alpha$ and IL-1Ra may be associated with increased susceptibility to autoimmune disease, including rheumatoid arthritis and Wegener's granulomatosis. ${ }^{16-19}$ An imbalance in production of the inflammatory cytokines relative to their inhibitors could result in an acute inflammatory process either being exaggerated 
Table 1 Comparison of the TNF- $\alpha$ and IL-1Ra genotypes among corneal melting patients and controls

\begin{tabular}{|c|c|c|c|}
\hline \multirow[b]{2}{*}{ Genotype } & \multicolumn{2}{|c|}{ Subjects $(n=20)$} & \multirow[b]{2}{*}{ Controls $(n=202)$} \\
\hline & $R A$ & $W G$ & \\
\hline \multicolumn{4}{|c|}{ TNF- $\alpha$ genotypes (position -308 ) } \\
\hline 1,1 & 12 & 2 & 134 \\
\hline 1,2 & 4 & 1 & 56 \\
\hline \multirow[t]{2}{*}{2,2} & 1 & & 12 \\
\hline & \multicolumn{2}{|c|}{ Subjects $(n=20)$} & \\
\hline Genotype & $R A$ & $W G$ & Controls $(n=200)$ \\
\hline \multicolumn{4}{|c|}{ IL-1 Ra genotype } \\
\hline 1,1 & 11 & 3 & 127 \\
\hline 1,2 & 4 & & 52 \\
\hline 1,3 & 1 & & 6 \\
\hline 2,2 & 1 & & 14 \\
\hline 4,4 & - & & 1 \\
\hline
\end{tabular}

or becoming chronic. There is some evidence to suggest that this situation occurs in the rheumatoid synovium and in corneal melting. ${ }^{20}{ }^{21}$ Given the association with the underlying autoimmune diseases and the functional significance of the TNF- $\alpha$ and IL-1Ra polymorphisms, we postulated a role for these polymorphisms in the pathogenesis of corneal melting. Here we report the genotype and allele frequencies of these polymorphisms in patients with vasculitis associated necrotising keratitis or corneal melting and in the normal population from the same geographical area.

\section{Patients and methods}

After ethics committee approval had been obtained, patients in the Yorkshire Region with a diagnosis of sterile corneal melting in association with systemic vasculitis were invited to take part in the study. The anatomical site of the corneal melting and the systemic disease association were determined from case note review, clinical and slit lamp examination, or both.

DNA was extracted from peripheral blood lymphocytes using a previously described method comprising red cell lysis, proteinase $\mathrm{K}$ digestion, salt extraction, and ethanol precipitation. ${ }^{22}$ At a concentration of $0.1 \mu \mathrm{g} / \mu \mathrm{l}$, the DNA was subjected to polymerase chain reaction (PCR) amplification in a GeneAMP PCR System 9600 (Perkin Elmer, CA, USA). The products were analysed by electrophoresis on agarose gels and visualised by ultraviolet transillumination with ethidium bromide staining. A molecular weight marker ranging from $100 \mathrm{bp}$ to $600 \mathrm{bp}$ was used to determine the fragment sizes.

Table 2 Frequency of each allele (\%) of TNF-a and IL-1Ra in the combined patient and control groups and the relative risk (RR)

\begin{tabular}{|c|c|c|c|}
\hline Allele & Subjects & Controls & $R R$ \\
\hline G/TNF1 & 82.5 & 80.2 & 1.03 \\
\hline $\mathrm{A} / \mathrm{TNF} 2$ & 17.5 & 19.8 & 0.88 \\
\hline IL- $1 \mathrm{Ra}^{\star} 1$ & 82.5 & 78.3 & 1.06 \\
\hline IL- $1 \mathrm{Ra}^{\star} 2$ & 15 & 20 & 0.79 \\
\hline IL $-1 \mathrm{Ra}^{\star} 3$ & 2.5 & 1.5 & 1.67 \\
\hline IL- $1 \mathrm{Ra}^{\star} 4$ & - & 0.2 & - \\
\hline IL $-1 \mathrm{Ra}^{\star} 5$ & - & - & - \\
\hline
\end{tabular}

PCR ANALYSIS OF TNF- $\alpha$ GENE POLYMORPHISM PCR amplification of the polymorphic region at position -308 of the TNF- $\alpha$ promoter region was performed using previously described primers and subjected to specific endonuclease digestion with Nco $1 .{ }^{23}$ PCR conditions were as follows: $94^{\circ} \mathrm{C}$ for 3 minutes, $60^{\circ} \mathrm{C}$ for 1 minute, $72^{\circ} \mathrm{C}$ for 1 minute, followed by 35 cycles of $94^{\circ} \mathrm{C}$ for 1 minute, $59^{\circ} \mathrm{C}$ for 1 minute, $72^{\circ} \mathrm{C}$ for 1 minute and a final cycle of $94^{\circ} \mathrm{C}$ for 1 minute, $60^{\circ} \mathrm{C}$ for 1 minute, and $72^{\circ} \mathrm{C}$ for 1 minute. The resultant PCR products were separated by electrophoresis on a $4 \%$ agarose gel and visualised under ultraviolet transillumination. When the TNF1 allele is present, the Nco1 restriction site is intact and an $84 \mathrm{bp}$ product is produced. For the TNF2 allele, the PCR product cannot be cleaved by Ncol and a 108 bp product is produced. ${ }^{23}$

PCR ANALYSIS OF IL-IRA GENE POLYMORPHISM Intron 2 of the IL-1Ra gene contains an $86 \mathrm{bp}$ VNTR. Primers flanking this region were used to amplify the polymorphic region by PCR. ${ }^{12}$ PCR conditions were as follows: $94^{\circ} \mathrm{C}$ for 1 minute, $60^{\circ} \mathrm{C}$ for 1 minute, $72^{\circ} \mathrm{C}$ for 1 minute followed by 35 cycles of $94^{\circ} \mathrm{C}$ for 1 minute, $59^{\circ} \mathrm{C}$ for 1 minute, $72^{\circ} \mathrm{C}$ for 1 minute and a final cycle of $94^{\circ} \mathrm{C}$ for 1 minute, $60^{\circ} \mathrm{C}$ for 1 minute, and $72^{\circ} \mathrm{C}$ for 1 minute. The PCR products were separated by electrophoresis on a $2 \%$ agarose gel and visualised under ultraviolet transillumination. The IL-1Ra alleles exist as variable numbers of the tandem repeat and as PCR products of the following sizes: IL- $1 \mathrm{Ra}^{\star} 1=410 \mathrm{bp}, \mathrm{IL}-1 \mathrm{Ra}{ }^{\star} 2=240 \mathrm{bp}$, IL-1 $\mathrm{Ra}^{\star} 3=500 \mathrm{bp}, \mathrm{IL}-1 \mathrm{Ra}^{\star} 4=325 \mathrm{bp}$, and IL $-1 \mathrm{Ra}^{\star} 5=595 \mathrm{bp}$.

After determining the genotype for each patient, the allele frequencies (number of times the test allele occurs in the population divided by the total number of alleles) for each of the alleles encountered were calculated. The genotype and frequency of the alleles was then compared with that for unrelated white blood donor controls from the Yorkshire area (J Reid, personal communication).

Statistical analysis was performed using $2 \times 2$ contingency tables and $\chi^{2}$ tests to calculate the relative risk and significance for each allele.

\section{Results}

Twenty white patients were recruited into the study, of whom 17 had rheumatoid arthritis and three had Wegener's granulomatosis. Ten of the patients were male. All the patients had peripheral corneal melting, except for one with rheumatoid arthritis in whom the disease was central and bilateral.

The distribution of the genotypes found in the patients with rheumatoid arthritis or Wegener's granulomatosis and in the control groups is given in Table 1. The frequency of each allele in the combined patient group and the control group is given in Table 2 . Although there was a trend for the IL- $1 \mathrm{Ra}^{\star} 2$ allele to be more common in the control group, this failed to reach clinical significance. No allele was found to be 
significantly associated with the patient group: TNF $1 \mathrm{p}=0.89 ;$ TNF2 $\mathrm{p}=0.89 ;$ IL- $1 \mathrm{Ra}^{\star} 1 \mathrm{p}=$ 0.65 ; IL-1 Ra ${ }^{\star} 2 \mathrm{p}=0.68$; IL-1Ra ${ }^{\star} 3 \mathrm{p}=0.50$.

\section{Discussion}

Necrotising keratitis or corneal melting occurs most commonly in association with a systemic vasculitis. ${ }^{14}$ The condition may occur in either the central or peripheral cornea and is characterised by ulceration and rapidly progressive loss of the corneal stroma. The pathogenesis of the condition is poorly understood but a combination of factors appears to be involved, including chronic ocular surface disease and inflammatory cell infiltrate. ${ }^{82} 25$ Although a tendency exists for the inflammatory ulceration to occur more commonly in the peripheral cornea and for the surface disease associated ulceration to occur in the central or paracentral cornea, this distinction is not absolute and most patients have a combination of surface disease and inflammatory cell infiltrate. ${ }^{26}$ In our experience, the inflammatory process in the cornea of patients with either anatomical type of vasculitis associated corneal melting is quantitatively very different from that in other patients with the same systemic vasculitis and ocular surface disease but no melting. In this study, we planned to investigate whether this difference may be a reflection of an inherent imbalance in cytokine production relative to the corresponding inhibitor in these patients.

In the normal immune response, inflammation produces little or no damage to the host. However, if the response is self directed and/or ineffectively downregulated, then a situation of chronic leucocyte activation arises with continued production of inflammatory mediators and tissue destruction. This may be the case in the corneal melting associated with rheumatoid arthritis and Wegener's granulomatosis. ${ }^{21}$ In addition to inflammatory cell infiltrate and surface disease, features of the ocular condition include local vasculitis, an excess of matrix metalloproteinases relative to their tissue inhibitors, and rapid loss of corneal stroma often progressing to perforation. ${ }^{21}{ }^{24}{ }^{27}$ In view of the role of TNF- $\alpha$ and IL-1Ra in the pathogenesis of systemic vasculitis and their presence in normal and inflammatory corneal disease, it seemed reasonable to determine the role of functional polymorphisms of these cytokines in the susceptibility to corneal melting.

Given the similar genotypes in the patients with rheumatoid arthritis and Wegener's granulomatosis and the small number of patients with the latter, the allele frequencies were calculated for the whole patient group (Table 2). Similar frequencies of all the TNF- $\alpha$ and IL-1 Ra alleles were observed in patients with corneal melting and healthy controls from the same ethnic group and geographic area. Most of these alleles are biologically silent and only the TNF2 and IL- $1 \mathrm{Ra}^{\star} 2$ alleles have functional significance. There was no evidence to suggest that the functional allele TNF2 was more common and the IL- $1 \mathrm{Ra}^{\star} 2$ allele less common in the patient group. Such a finding would have supported our original hypothesis. However, the number of patients is small and so this study is underpowered. As corneal melting in the context of systemic vasculitis is extremely rare, a multicentre project would be needed to show statistical significance given the similar allele frequencies. ${ }^{28}$ We have not investigated all of the possible ligand, receptor, and antagonist alleles for TNF- $\alpha$ and IL-1. Our impression from this study is that the alleles of TNF- $\alpha$ at position -308 and within intron 2 of the IL-1Ra gene have either no or a limited role in the susceptibility to corneal melting in this patient group.

Controversy exists with regard to the role of TNF- $\alpha$ and IL- 1 Ra alleles in relation to other immune disease. Some studies have shown an increased susceptibility to autoimmune disease, including rheumatoid arthritis and Wegener's granulomatosis. ${ }^{16-18}$ However, these associations are modest and the findings were not supported by other studies. ${ }^{29-31}$ Given the multifactorial pathogenesis of these systemic diseases, it may be unlikely that a single mutation can confer increased susceptibility. ${ }^{18}{ }^{19}$ There is other evidence to support a role for individual alleles in determining the severity of a given autoimmune disease. ${ }^{162}$ Alleles of TNF- $\alpha$ may alter the profile of rheumatoid disease. ${ }^{19}{ }^{30} \mathrm{In}$ relation to ocular disease, variant $\mathrm{TNF}-\alpha$ alleles may be responsible for altered levels of TNF- $\alpha$ in the tear film and a poor outcome while IL-1 alleles may predispose to chronic iritis in juvenile rheumatoid arthritis. ${ }^{32}{ }^{33}$ It proved difficult to try to classify this small group of patients with corneal melting in terms of the severity of the ocular disease. Using the less common alleles TNF2 and IL- $1 \mathrm{Ra}^{\star} 2$ as independent risk factors, we attempted to determine their influence on the disease severity using the following as examples of measures of severity: unilateral or bilateral disease, perforation requiring corneal grafting, number of corneal grafts, and final visual outcome. However, we were unable to devise a useful measure of disease severity which could be reliably applied to such a retrospective review of the patients and case notes. Not only were the systemic associations different, but so too was the local and systemic immunotherapy before and after presentation, the stage of the disease at the initial presentation, and the relative contribution of ocular surface and inflammatory disease. Our overall impression from a retrospective case note review was that the functional alleles studied were not associated with increased severity of ocular disease.

In summary, the genotype and allele frequencies of the TNF- $\alpha$ and IL-1Ra sites studied did not differ significantly between the patient and control groups. As a result of this study, we conclude that these polymorphic alleles play little or no part in either the susceptibility to or the severity of corneal melting in these patients with systemic vasculitis.

This work of this project was performed by MM at St James's University Hospital, Leeds and was supported by a grant from the Northern and Yorkshire Regional Health Authority.

1 Arend WP, Malyak M, Guthridge CJ, et al. Interleukin-1 receptor antagonist: role in biology. Annu Rev Immunol 1998;16:27-55. 
2 Gamache GA, Dimitrijevich SD, Weimer LK, et al. Secretion of proinflammatory cytokines by human con-
junctival epithelial cells. Ocul Immunol Inflamm 1997;5: junctival

3 Kenedy MC, Rosenbaum JT, Brown J, et al. Novel production of interleukin-1 receptor antagonist peptides in norma human cornea. F Clin Invest 1995;95:82-8.

4 Sotozono C, He J, Matsumoto Y, et al. Cytokine expression in the alkali-burned cornea. Curr Eye Res 1997;16:670-6.

5 Jones DT, Monroy D, Ji Z, et al. Alterations of the ocular surface gene expression in Sjogren's syndrome. $A d v$ Exp Med Biol 1998;438:533-6.

6 Sneller MC, Fauci AS. Pathogenesis of the vasculitis syndromes. Med Clin N Am 1997;81:221-42.

7 Maini RN. The role of cytokines in rheumatoid arthritis. $\mathcal{f}$ Roy Coll Phys 1996;30:344-51.

8 Kervick GN, Pflugfelder SC, Haimovici R, et al. Paracentral rheumatoid corneal ulceration: clinical features and cyclosporine therapy. Ophthalmology 1992;99:80-8.

9 Strissel KJ, Rinehart WB, Fini ME. A corneal epithelial inhibitor of stromal cell collagenase synthesis identified as TGF-beta 2. Invest Ophthalmol Vis Sci 1995;36:151-62.

10 Wilson AG, di Giovine FS, Duff GW. Genetics of tumour necrosis factor-alpha in autoimmune, infectious, and neoplastic diseases. F Inflamm 1995;45:1-12.

11 Kroeger KM, Carville KS, Abraham LJ. The -308 tumour necrosis factor-alpha promoter polymorphism effects transcription. Mol Immunol 1997;34:391-9.

12 Tarlow JK, Blakemore AIF, Lennard A, et al. Polymorphism in human IL-1 receptor antagonist gene intron 2 is caused by variable numbers of an $86-\mathrm{bp}$ tandem repeat. Hum Genet 1993;91:403-4.

13 Danis VA, Millington M, Hyland VJ, et al. Cytokine production by normal human monocytes: inter-subject variation and relationship to an IL-1 receptor antagonist gene polymorphism. Clin Exp Immunol 1995;99:303-10.

14 Foster CS, Forstot SL, Wilson LA. Mortality rate in rheumatoid arthritis patients developing necrotising scleritis or peripheral ulcerative keratitis. Ophthalmology 1984; tis or periph

15 Arend WP, Dayer JM. Inhibition of the production and effects of interleukin-1 and tumour necrosis factor alpha in rheumatoid arthritis. Arthritis Rheum 1995;38:151-60.

16 Blakemore AI, Tarlow JK, Cork MJ, et al. Interleukin-1 receptor antagonist gene polymorphism as a disease severity factor in systemic lupus erythematosus. Arthritis Rheum 1994;37:1380-5.

17 Danis VA, Millington M, Hyland V, et al. Increased frequency of the uncommon allele of a tumour necrosis factor alpha gene polymorphism in rheumatoid arthritis and systemic lupus erythematosus. Disease Markers 1995; 12:127-33.

18 Mascher B, Schmitt W, Csernok E, et al. Polymorphisms in the tumour necrosis factor genes in Wegener's granulomatosis. Exp Clin Immunogenet 1997;14:226-33.
19 Vinasco J, Beraun Y, Nieto A, et al. Polymorphism at the TNF loci in rheumatoid arthritis. Tissue Antigens 1997;49: 74-8.

20 Firestein GS, Boyle DL, Yu C, et al. Synovial interleukin-1 receptor antagonist and interleukin-1 balance in rheumatoid arthritis. Arthritis Rheum 1994;37:644-52.

21 Riley GP, Harrall RL, Watson PG, et al. Collagenase (MMP-1) and TIMP-1 in destructive corneal disease associated with rheumatoid arthritis. Eye 1995;9:703-18.

22 Miller SA, Dykes DD, Polesky HT. A simple salting out procedure for extracting DNA from human nucleated cells. Nucl Acids Res 1988;16:1215.

23 Wilson AG, di Giovine FS, Blakemore AI, et al. Single base polymorphism in the human tumour necrosis factor alpha (TNF-alpha) gene detectable by Ncol restriction of the PCR product. Hum Mol Genet 1992;1:353.

24 Bernauer WG, Ficker LA, Watson PG, et al. The management of corneal perforations associated with rheumatoid arthritis. Ophthalmology 1995;102:1325-37.

25 Watson PG. Vascular changes in peripheral corneal destructive disease. Eye 1990;4:65-73.

26 Pfister RR, Murphy GE. Corneal ulceration and perforation associated with Sjogren's syndrome. Arch Ophthalmol 1980;98:89-94.

27 Tauber J, de la Maza MS, Hoang-Xuan T, et al. An analysis of therapeutic decision making regarding immunosuppressive chemotherapy for peripheral ulcerative keratitis. Cornea 1990;91:66-73.

$28 \mathrm{M}$ McKibbin, J D Isaacs, A J Morrell. The incidence of corneal melting in association with systemic vasculitis in the Yorkshire Region, 1995-1997. Br f Ophthalmol 1999;83: 941-3.

29 Wilson AG, de Vries N, van der Putte LB, et al. A tumour necrosis factor alpha is not associated with rheumatoid arthritis. Ann Rheum Dis 1995;54:601-3.

30 Brinkman BM, Huizinga TW, Kurban SS, et al. Tumour necrosis factor alpha gene polymorphisms in rheumatoid arthritis: association with susceptibility to, or severity of, disease? Br F Rheumatol 1997;36:516-21.

31 Danis VA, Millington M, Huang Q, et al. Lack of an association between an interleukin-1 receptor antagonist gene polymorphism and systemic lupus erythematosus. Disease Markers 1995;12:135-9.

32 McDowell TL, Symons JA, Ploski R, et al. A genetic association between juvenile rheumatoid arthritis and a novel interleukin-1 alpha polymorphism. Arthritis Rheum 1995; 38:221-8.

33 Conway DJ, Holland MJ, Bailey RL, et al. Scarring trachoma is associated with polymorphism in the tumour necrosis factor alpha (TNF-alpha) gene promoter and with elevated TNF-alpha levels in tear fluid. Infect Immun 1997; 65:1003-6. 